Abstracta Iranica Iranica

Revue bibliographique pour le domaine irano-aryen

Volume 32-33 | 2013

Comptes rendus des publications de 2009-2010

Nile Green. The Uses of Books in a Late Mughal

Takiyya: Persianate Knowledge Between Person and

Paper

Mauro Valdinoci

(2) OpenEdition

Journals

Electronic version

URL: http://journals.openedition.org/abstractairanica/40632

DOI: $10.4000 /$ abstractairanica.40632

ISSN: 1961-960X

Publisher:

CNRS (UMR 7528 Mondes iraniens et indiens), Éditions de l'IFRI

Printed version

Date of publication: 1 December 2013

ISSN: 0240-8910

Electronic reference

Mauro Valdinoci, « Nile Green. The Uses of Books in a Late Mughal Takiyya: Persianate Knowledge Between Person and Paper», Abstracta Iranica [Online], Volume 32-33 | 2013, document 277, Online since 01 July 2016, connection on 03 October 2020. URL : http://journals.openedition.org/ abstractairanica/40632 ; DOI : https://doi.org/10.4000/abstractairanica.40632

This text was automatically generated on 3 October 2020.

Tous droits réservés 


\title{
Nile Green. The Uses of Books in a Late Mughal Takiyya: Persianate Knowledge Between Person and Paper
}

\author{
Mauro Valdinoci
}

\section{REFERENCES}

Nile Green. « The Uses of Books in a Late Mughal Takiyya: Persianate Knowledge

Between Person and Paper ». Modern Asian Studies, vol. 44, n² 2, 2010, p. 241-65.

1 This article addresses the relation between books and the concept and organization of knowledge in the late Mogul Era. An analysis of how books were used in a Sufi lodge in Awrangabad connects the shifts observed there to the broader political context of the expansion of Mogul power and its complex bureaucracy. The chief aim of this article is to point to a crucial tension and transition in the Persianate culture of early modern India between "anthropocentric" and "bibliocentric" approaches to the circulation of knowledge. Exploring the religious and bureaucratic aspects of the production and consumption of books, the author emphasizes how the growing scale of the Mogul bureaucracy led to changes in the modes and means of knowledge. The intensification and diffusion of bureaucratic forms of writing led to a conceptual rearrangement of knowledge, a shift from programs of textual and non-textual learning under the close supervision of a master to the more autonomous, bibliocentric patterns of education based on the private reading and copying of books. 


\section{AUTHORS}

\section{MAURO VALDINOCI}

University of Modena and Reggio Emilia 